Werner Gresse, Bennie Linde, René Schalk*

\title{
Sense of deservingness: What are the entitlement beliefs of students in their anticipatory psychological contract? ${ }^{* *}$
}

Without taking the entitlement beliefs and reasons therefore into account when examining the psychological contract of an individual, a full view on the psychological contract and its expected consequences cannot be achieved. Therefore the purpose of the paper was to explore and substantiate themes associated with perceived entitlements and utilise this information to develop a structural model of the anticipatory psychological contract. The findings suggest that there are certain factors that determine an individual's entitlement beliefs, and in turn that individual's entitlement beliefs will influence the level of expectation of that individual regarding future employment. By fully comprehending the effects of the entitlement beliefs on the anticipatory psychological contract of prospective employees the organisation may minimise the occurrence of psychological breach or violation, which may decrease new employee turnover.

Key words: entitlement, anticipatory, psychological contract, graduates (JEL: J24, J28, J59, J63)

* Werner Gresse, PhD student at the Potchefstroom campus of the North-West University (South Africa), WorkWell Research Unit. North-West University, Private Bag X6001, Potchefstroom, 2520,SouthAfrica. E-mail: 20385226@nwu.ac.za.

Dr. Bennie Linde, associate professor at the Potchefstroom campus of the North-West University (South Africa), WorkWell Research Unit. North-West University, Private Bag X6001, Pothcefstroom, 2520, South Africa. E-mail: bennie.linde@nwu.ac.za.

Prof. Dr. René Schalk, Professor René Schalk, Department of Human Resource Studies, Tilburg University, PO Box 90153, 5000 LE Tilburg. Extraordinary Professor at WorkWell Research Unit, North-West University (South Africa).

E-mail: m.j.d.schalk@uvt.nl.

** The financial assistance of the National Research Foundation (NRF) towards this research is hereby acknowledged. Opinions expressed and conclusions arrived at, are those of the authors and are not necessarily to be attributed to the NRF.

Article received: February 6, 2013

Revised version accepted after double blind review: November 22, 2013. 


\section{Introduction}

Rousseau (2001) claims that the beliefs included in the psychological contract are formed in the recruiting process, as well as during the socialisation process when first starting employment. However, according to De Vos, Stobbeleir, and Meganck (2009), the majority of adolescent graduates have no frame of reference based on earlier professional experience that can shape their psychological contract. Nevertheless, before graduates commence formal employment they already develop a mental schema that determines not only their choice of employment, but also the evaluation framework they will use to determine the extent to which their expectations match the reality after organisational entry. De Vos et al. (2009) confirm that the obligations that are prominent in graduate pre-employment beliefs are likely to affect the psychological contract. From an employee's viewpoint, the psychological contract includes what is assumed of the organisation's promises or claims, such as an above average salary or more benefits, in exchange for the employee's commitment and contributions to the organisation (Turnley, Bolino, Lester, \& Bloodgood, 2003).

Fisk (2010) and Twenga and Campbell (2009) have suggested that we were currently living in the "Age of Entitlement". It is the abovementioned authors' perception that there is a tendency that individuals are increasingly subscribing to the belief that they should get what they want, when they want it, even if that means they will have to affect the well-being of others negatively. This occurrence in which individuals consistently believe that they deserve preferential rewards and treatment, often with little consideration of actual qualities or performance levels, is regarded as perceived or psychological entitlement (Fisk, 2010; Harvey \& Harris, 2010; Harvey \& Martinko, 2009; Snyders, 2002). According to Snyders (2002) entitlement can be seen as a "sense of deservingness" (p. 21).

The occurrence of perceived entitlement has grown vastly in the last decade and is now influencing life in many of the social institutions, including entitlement in education (Greenberger, Lessard, Chen, \& Farruggia, 2008) and family inheritance (Allers, 2005; Tyre, Scelfo, \& Kantrowitz, 2004). Most of the existing research conducted on perceived entitlement did focus on the social context (Exline, Baumeister, Bushman, Campbell, \& Finkel, 2004; Schwartz \& Tylka, 2008). Entitlement in the workplace context has only recently been subject of study (Fisk, 2010; Harvey \& Harris, 2010; Harvey \& Martinko, 2009; Kets de Vries, 2006; Levine, 2005). Naumann, Minsky, and Sturman (2002) state that perceived entitlement is an important concept in organisational sciences since understanding an employee's perception of entitlement is essential to understanding the expectations of that employee and, in particular, the nature of exchange between employees and the organisation. The comprehension of an individual's entitlement perceptions is important because this will affect the shape of the psychological contract, which in turn affects attitudes and behaviours of employees in the workplace (Robinson \& Rousseau, 1994).

According to Harvey and Harris (2010) unrealistic entitlement perceptions can cause problems for both employees and employers. Snyders (2002) says there should be a warning to individuals who are in the process of attaining "something special" ( $p$. 22), like a degree or diploma, and then fall subject to the danger of unrealistic entitle- 
ment beliefs. Ochse (2005) reports on a study conducted by the University of South Africa that determined the academic expectation and perceptions of university students, and found that all the participants from the study had fairly high expectations for future success and that these students believed that they were intellectually above average. Furthermore, Ochse (2005) found that students from all racial and gender groups overestimated their future success, where it was confirmed that they had lower actual achievement. This finding confirms that it is important to create the link between entitlement perceptions and expectations to fully comprehend the psychological contract of a prospective employee.

Research that focussed on perceived entitlement in the work context found that employees with unrealistic entitlement beliefs displayed a tendency toward unethical behaviour and conflict with their supervisors, high pay expectations, low levels of job satisfaction, high levels of turnover intention, perceived inequity, job dissatisfaction and even corruption (Harvey \& Harris, 2010; Harvey \& Martinko, 2009; Kets de Vries, 2006; Levine, 2005). It has also been suggested that perceived entitlement can negatively affect the judgment of individuals in leadership positions (Levine, 2005).

The theoretical problem addressed in this study is that we expand psychological contract theory by making a distinction between perceived entitlements and obligations and expectations. Without taking the entitlement beliefs and reasons therefore into account when examining the psychological contract of an individual, a full view on the psychological contract and its expected consequences cannot be achieved.

The aim of this study is to explore and substantiate themes associated with perceived entitlement and use this information to purpose a structural model of the anticipatory psychological contract that will broaden the scope of perceived entitlement literature in the work context by using a qualitative method of research.

To achieve the purpose of this study a literature review was conducted regarding the origins of the psychological contract and perceived entitlement, which laid the foundation for the exploration of perceived entitlement and expectations of the participants. After the literature review three research propositions were formulated, which provided the foundation for the reporting of the results.

\section{Literature review}

\section{Origins of the psychological contract}

It is necessary to understand the origins of the psychological contract before perceived entitlement can be explored. This is due to the fact that entitlement perceptions affect an individual's expectations (Naumann et al., 2002), and expectations form part of the individual psychological contract (Freese \& Schalk, 2008; Van den Heuvel \& Schalk, 2009; Paul, Niehoff, \& Turnley, 2000).

According to Linde (2007) the concept of the psychological contract has vastly grown since the 1990s although it was first used in the work context by Argyris in the 1960s. Levinson, Price, Munden, Mandl, and Solley (1962) elaborated the psychological contract by explaining it as an exchange relationship between employer and employee in which each party has expectations about mutual obligations. Rousseau (1989) defined the psychological contract as an individual's belief regarding the terms 
and conditions of a reciprocal exchange agreement between that central person and another party. As such the psychological contract can be seen as a set of beliefs about what the employee and employer expect to receive, and are compelled to award, in exchange for the other party's contribution (Levinson et al., 1962).

According to Rousseau (1995) the individual psychological contract is different from other types of contracts, such as the social contract (this includes the labour legislation and other societal norms), the legal contract (this is the formal employment contract), and the normative contract (this usually are the norms of the groups the individual associate with). These concepts are illustrated in Table 1. Each individual has a unique psychological contract based on his/her own understanding of obligations towards the organisation (Turnley \& Feldman, 1999). Employees with balanced psychological contracts are less likely to want to leave a relationship, such as an employment relationship (Scott, Eau, \& Jill, 2001). Psychological contract breach occurs when an employee experiences that the organisation did not live up to its requirements and commitments (Restubog, Bordia, \& Tang, 2006; Turnley et al., 2003).

Table 1: Different types of contracts

\begin{tabular}{|c|c|c|}
\hline & Individual & Group \\
\hline 弄 & $\begin{array}{l}\text { Psychological contract } \\
\text { Individual beliefs regarding promises } \\
\text { made, accepted, and relied between } \\
\text { themselves and others. }\end{array}$ & $\begin{array}{l}\text { Normative contract } \\
\text { Shared psychological contract that emerges } \\
\text { when members of a social group, organisation } \\
\text { or work unit hold common beliefs. }\end{array}$ \\
\hline 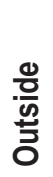 & $\begin{array}{l}\text { Implied contract } \\
\text { Interpretations that third parties make } \\
\text { regarding contractual terms. }\end{array}$ & $\begin{array}{l}\text { Social contract } \\
\text { Broad beliefs in obligations associated with a } \\
\text { society's culture. }\end{array}$ \\
\hline
\end{tabular}

Source: Rousseau (1995, p. 9)

According to Morrison and Robinson (1997) and Paul et al. (2000) a failure to meet the employee's expectations on obligations may result in a breach of the psychological contract between the employee and employer. Previous research regarding entitlement perceptions found that the failure of organisations to meet entitlement beliefs of individuals leads to higher levels of turnover intention, perceived inequity and job dissatisfaction, which also constitutes breach of the psychological contract (Harvey \& Harris, 2010). If a breach is significant, it constitutes an experience of violation (Morrison \& Robinson, 1997). Hellgren (2003) and Linde (2007) defined a breach as the cognitive perception an employee experiences when the organisation has failed to uphold one or more aspects of the psychological contract. On the other hand, a violation of the psychological contract refers to the emotional and affective reactions, such as those that could arise when an employee felt that the organisation had failed to properly 
maintain its end of the psychological contract (Linde, 2007; Morrison, \& Robinson, 1997).

Since 1960, when research began on the psychological contract, expectations were considered interrelated to the psychological contract (Freese \& Schalk, 2008; Van den Heuvel \& Schalk, 2009; Paul et al., 2000). The Oxford Dictionary (2010) defines expectation as a strong belief about the way something should happen or how somebody should behave. When entering an employment relationship, people tend to develop certain expectations about that relationship. Employees learn what the other party (employer) expects them to contribute and in return these employees develop ideas about what they should receive for services rendered to the employer (Heath, Knez, \& Camerer, 1993). Sutton and Griffin (2004) used the term "pre-entry expectations" to refer to newcomer expectations that were formed prior to actual employment. These implicit or explicit expectations constitute the basis for the perceived obligations of the contract - the psychological contract - in a relationship.

\section{Perceived entitlement and expectations}

According to VandenBos (2006) the word entitlement refers to the right or benefits legally bestowed on a person or group, for instance through legislation or a contract, or unreasonable claims to special consideration (the latter referring to psychological entitlement). When considering the definition of psychological entitlement, as mentioned above, it is also relevant to take into account the definition of entitlement perceptions in the workplace according to Naumann et al. (2002). These authors defined entitlement perceptions in the workplace as "the compensation expected as a result of an individual participating in an employment relationship" (p. 150).

Snyders (2002) suggested that perceived entitlement or sense of deservingness may become a sort of identity which presupposes the individual's own rights and needs. According to Snyders (2002) these needs include rights such as the right to status and power, others' mind and bodies, space and place, not to pay attention to other peoples' reactions, be empathic, view of life as a constant battle, winning and losing (with losing resulting in shame and humiliation for the individual), blame outwards and blame others without considering one's own role in problems and processes, and to view oneself as superior.

Even though it has been argued that nearly every person displays at least some degree of perceived entitlement (Boyd \& Helms, 2005), each individual appears to differ in the level of entitlement (Campbell, Bonacci, Shelton, Exline, \& Bushman, 2004). Campbell et al. (2004) found evidence suggesting that perceived entitlement levels are stable over time and argued that it is stable across situations as well.

Snyders (2002) described the word "sense of deservingness" as an attitude or way of viewing life. According to Harvey and Harris (2010) a person or group may also feel a sense of entitlement due to factors within that person or group. Harvey and Harris (2010) refer to this specific perception of entitlement as psychological entitlement; thus, psychological entitlement can be defined as a fairly stable and universal characteristic that occurs when an individual expects a high level of reward or preferential treatment regardless of his/her ability and performance level (Campbell et al., 2004; Harvey \& Harris, 2010). According to Snyders (2002) individuals with high per- 
ceived entitlement levels believe that they are owed many things in life where they do not have to earn what they get; that they are just entitled to it because of who they are or whom they are associated with.

The difference between expectations on obligations and entitlements has to do with the "sense of deservingness". Where expectations on obligations refer to the individual's anticipation to receive something, entitlements refer to the perceived right of the individual to receive something, even in absence of a formal or informal agreement. The level of an individual's expectations is of course influenced by the entitlement beliefs of that individual (Naumann et al., 2002). Although entitlement was mentioned in previous psychological contract studies (Rousseau, 1998; Paul et al., 2000) it has never been investigated as a separate component of the psychological contract.

The following research questions were derived from the above literature review:

Research question 1: Which expectations (individual expectations) do students have due to their entitlement beliefs?

Research question 2: Which general expectations (normative expectations) do students have regarding future employment?

Research question 3: Which factor influences the entitlement beliefs of students?

\section{Research design}

\section{Research approach}

This paper is exploratory in nature. Due to the lack of research on this subject a qualitative approach to data gathering is applied to derive themes associated with expectations and entitlement beliefs. The questions that were developed were based on theoretical principles of entitlement beliefs and anticipatory psychological contracts. Identified themes were also discussed through a literature study. Trochim and Donnelly (2008) stated that the central reason why a researcher may consider doing a qualitative study is when the state of knowledge in an area is inadequate.

\section{Research strategy}

Interviews were conducted and the data gathered was transcribed to identify the various themes associated with expectations and perceived entitlement of the anticipatory psychological contract of prospective employees. This article is exploratory in nature due to the fact that there hasn't been much focus on perceived entitlement in psychological contract studies. For this reason, this article focuses on deriving themes associated with perceived entitlement of students through the use of semi-structured qualitative interviews. Using the themes as points of reference a model was introduced to illustrate the anticipatory psychological contract of prospective employees.

\section{Research method}

\section{Research setting}

The research population examined was made up of final year graduate and postgraduate students in economic and management programmes at a South African university who will enter the workplace within the next few years. All the participants were final year or post graduate labour relations or industrial psychology students. 


\section{Sampling}

Convenience sampling was used to select participants for the interviews. The number of interviewees was 20 and had equal representation of both genders. All participants were between the age range of 21 and 24. The sample consisted of 13 final year under graduate students (third year students) and 7 post graduate students (fourth year students) who have not yet entered formal employment. Only one of the students had relevant work experience which he acquired before he commenced his studies. The other participants started studying directly after school. Participation in the interviews was voluntary and complete anonymity in reporting the results was promised in an attempt to limit bias and to increase the overall honesty of the participants.

\section{Data collection method}

A semi-structured interview was conducted to obtain data from the participants. The length of the interviews was approximately 20 minutes each. The interviewer asked a predetermined question which the participant had to consider and respond to. Thus the response of the participant was open and unguided. If additional information was required from the participant the interviewer would ask the participant to provide additional information. The interview scheme consisted of six open questions.

1. the desirable work-related expectations of participants;

2. the normative work-related expectations of participants; and

3. the factors that determine the entitlement beliefs of the participants.

The desirable work-related expectations of participants were identified by asking the participants what they believed they were going to receive, in other words, what they regarded as an attractive salary, employment conditions and benefits when they commenced work after having completed their studies. The normative work-related expectations of the participants were obtained by asking the participants to clarify what they believed they should receive; what the absolute minimum was they would consider before entering the employment of the future employer.

To determine the factors that influenced the entitlement beliefs of prospective employees it was necessary to differentiate between what these prospective employees wanted and what they felt they should receive when they started formal employment. This was achieved by asking the participants how they would differentiate between what they as employee should receive in the workplace and what they wanted to receive in that workplace; in other words, why did they as prospective employees feel the organisation should provide for certain aspects before they would consider working there.

\section{Recording and data analysis}

The answers on each of the interview questions were transcribed and analysed separately to obtain themes associated with the purpose of the question. After this process the responses were documented using a coding system approach. This coding process was done in Microsoft Excel where a table was formed which captured each theme based on the responses from the participants. All the themes were captured in this table, regardless of how relevant it was to the question. Each time a participant men- 
tioned a theme that theme would receive a point, these points was then used to calculate a percentage which was used in the findings and interpretation section. After analysing 17 of the 20 transcribed interviews a saturation point was reached as no new data or themes came to light, although points were still assigned to each theme. After the coding process each response was grouped in terms of similarity. An encompassing construct was then assigned to each grouped response. The responses from the participants were clustered on the basis of similarity, and correlating subcategories were then grouped together. The clustered groups were assigned an explanatory heading representing the construct associated with entitlement beliefs and expectations of prospective employees. The coding was performed by the interviewer and also reviewed by the various authors.

\section{Reporting}

The findings will be reported separately for each research question. Derived constructs and themes associated with perceived entitlement and expectations of prospective employees are documented in the following section. Answers given by participants were categorised, and the predominant categories were identified.

After the presentation of the results a model is proposed that illustrates the anticipatory psychological contract of prospective employees, thus achieving the main purpose of this paper.

\section{Findings and interpretation}

From the participants responses there were two encompassing constructs identified: firstly themes associated with expectations of prospective employees, and secondly aspects that influence expectations of prospective employees.

\section{Research question 1:}

Which expectations (individual expectations) do students have due to their entitlement beliefs?

Results: The following individual expectations where identified from the participants' responses:

- Attractive remuneration and benefits

The first theme associated with what the participants wanted from their first formal employer was in monetary terms. When asked what the participants wanted from future employment, nearly all of them (95\%) stated that they would like an attractive salary.

In the interviews $16 \%$ of the participants stated that they expected to receive a salary of between R9 000 and R11 000 per month, which is approximately between the $40^{\text {th }}$ to $55^{\text {th }}$ percentiles of salaries of South Africans with a tertiary education (Statistics South Africa, 2010); $28 \%$ of the participants stated that they expected a salary of between R12 000 and R15 000 per month, which is approximately between the $60^{\text {th }}$ and $75^{\text {th }}$ percentiles of salaries of South Africans with a tertiary education (Statistics South Africa, 2010); 22\% of the participants stated that they expected a salary of between R16 000 and R18 000 per month, which is the approximately between the $80^{\text {th }}$ to $85^{\text {th }}$ percentiles of salaries of South Africans with a tertiary education (Statistics South Africa, 2010); 16\% of the partici- 
pants stated that they expected a salary of between R19 000 and R22 000 per month, which is approximately between the $85^{\text {th }}$ to $90^{\text {th }}$ percentiles of monthly salaries of South Africans with a tertiary education (Statistics South Africa, 2010); and $16 \%$ of the participants stated that they expected a salary higher than R25 000 per month, which is higher than the $90^{\text {th }}$ percentiles of monthly salaries of South Africans with a tertiary education (Statistics South Africa, 2010).

- Employee assistance programs

This theme refers to the desire of prospective employees to work for a company that cares for its employee as a specific individual and not as just another employee. A few of the responses from the participants that came out during the interview that pertain to this theme was:

"Well, company benefits would be great, but I think it is more important to step into a workplace where you know you as an employee is appreciated."

"I would like it if the company is focussed on keeping their personnel happy because a happy worker is a good worker."

"I would prefer it if the organisation is people and work orientated."

"It would be nice for me to be in an environment where I can explore and be able to deliver my best."

The majority of participants stated that they would prefer certain company benefits, the predominant benefits mentioned in interviews being a car allowance, relaxation facilities, cell-phone allowance, housing allowance and insurance benefits.

- Personal skills development opportunity, status in the workplace and career mobility

When attempting to determine the preferred positions of prospective employees, $65 \%$ of the participants stated that they would most probably start in a lower level position to familiarise themselves with their job and the circumstances that surrounds it, and then advance up the corporate ladder as their job-related skills, knowledge and experience increased. When asked what the participants would like to receive in future employment, some of them $(10 \%)$ stated that they wanted the opportunity to grow as an employee in the workplace with opportunity for future promotion. In other words, they wanted to know that they were not in a dead-end job and that their circumstances regarding salary, job title and status in their community could only improve over time. One of the participants actually confirmed the above statement when he/she said:

"I think the average starting salary is between thirteen and fifteen thousand rand, but that should go up in time because I am not going to work for that amount the rest of my life." Organisational assistance regarding skills development was also an aspect that some of the participants identified, for instance, one of the participants stated that:

"I would like a programme or something that can help me to develop as an employee, for instance, if the company came and said they would help finance study for my masters degree."

Interpretation of results. The individual expectations of prospective employees refer to a higher than average expectation level of these individuals or this group that has 
not entered formal employment yet. According to Kreitner and Kinicki (2008) the top five needs and desires of a person younger than 35 are: compensation, other benefits, health care, job security and flexibility to balance work-life issues.

Attractive salary was the first individual expectation that was identified from the participants' responses. This comes as no surprise as money is one of the top motivational reasons why individuals have to work. This finding is in line with existing literature, for example a 2006 job satisfaction survey report identified that compensation was one of the top five needs and desires for an individual in the age group thirty-five and younger (Kreitner \& Kinicki, 2008). This makes sense because higher levels of income are associated with a higher level of living standards. According to Mohr and Fourie (2006), as an individual's supply of income increases, that individual's demand for products will also increase.

A survey conducted by the South African Graduate Recruiter Association (SAGRA, 2011) regarding starting salaries of graduates in South Africa found that the median graduate starting salary for 2011 was about R130 000 per annum, which is approximately R10 000 per month (SAGRA, 2011). The highest starting salaries for 2011 were for positions at investment banks or fund managers, consulting firms, law firms and engineering or industrial companies, which each had a median starting salary in excess of R230 000; approximately R19 000 per month (SAGRA, 2011). Considering this, $84 \%$ of the participants expected a higher salary than the actual salary median for starting salaries of this related group.

The second individual expectation was employee assistance programs. This theme refers more to an external appreciation of an individual that is not necessarily jobrelated, but more a motivational approach that would make the employees feel part of the organisation by providing something more than just monetary reward. According to Grobler et al. (2006) most new employees were very enthusiastic to learn more about their job and the organisation after accepting a job offer. This process is known as socialisation. Socialisation is regarded as a process by which employees are transformed from complete outsiders to participating and effective members of an organisation (Kreitner \& Kinicki, 2008).

The final individual expectations included personal skills development opportunity, status in the workplace, and career mobility opportunities.

Research question 2:

Which general expectations (normative expectations) do students have regarding future employment?

Results: The following normative expectations were identified from the participants' responses:

- Reasonable remuneration and necessity benefits

When asked what the participants should receive from their future employer all the participants stated that they should receive a salary based on their individual perception of what they were entitled to. The minimum amount that the participants would settle for before considering a job was different for each participant.

- Reasonable conditions of employment and environment 
This theme pertains to the contract of employment as well as the physical work environment. Of the participants $20 \%$ stated that they should have a legitimate contract of employment that sets out exactly what is expected of them as employees.

- Employee development, well-being and respect

All of the participants did believe that they were entitled to certain company benefits that would promote their well-being as an employee; for instance, medical aid and pension were considered as necessities by the participants, especially if the nature of work made it obvious. Some of the participants even stated that they should get a car allowance if the company expected them to undertake workrelated travel. Of the participants $45 \%$ identified employee well-being as an entitlement belief that they should receive in the formal work environment when they commenced employment. Skills development and training opportunities for individuals were also regarded by the participants as a normative expectation.

Interpretation of results: According to De Vos et al. (2009) graduates already had a mental model that affected their expectations before they entered the workplace as a working individual. The average of these pre-entry expectations is regarded as the normative expectations.

The first normative expectation that was identified was reasonable remuneration and necessity benefits. It came as no surprise that money was the first entitlement belief that prospective employees identified because, according to Newell (2002), individuals work in order to gain the monetary reward which they then use to pay for the things they need in order to live (which constitutes necessities), and to pay for luxuries (which constitutes desire). In other words, without money employees can't cover their expenditure. This indicates that their entitlement belief is set on survival of the individual, with some minor reference to money invested on qualification levels. When asked what the minimum amount was that the participants would work for (settle for), each gave a different amount, which reinforces the notion that an individual's entitlement beliefs determine that individual's expectation level.

The second normative expectation was reasonable conditions of employment and environment, and referred to the contract of employment. This expectation was in a way more a legitimate entitlement, as it is governed by law or legislation. An interesting finding from the interviews was the following response:

"I have previous work experience, so I believe should get a bigger salary and better conditions of employment because I am more qualified than my fellow graduates."

This statement confirms that perceived entitlement is part of the psychological contract due to the fact that this individual feels a legitimate right (entitlement) to receive a better salary and work conditions than other fellow graduates that have no previous work experience, and it is the obligation of the organisation to meet these entitlement demands.

The third normative expectation that was identified was employee development and well-being and respect in the workplace. This normative expectation is very similar to the theme mentioned earlier, regarding employee assistance programs. But in this theme employer development and well-being pertain more to the well-being of an 
employee of the organisation. The participants believed that the organisation should cater for their needs as employees of that company. According to Grobler et al. (2006) it is known that motivated employee behaviour is best achieved by integrating personal goals with the goals of the organisation. In other words, the difference between the first theme (employee assistance programs) and this one is the fact that the company that cares for its employees gives more external (individual) care, and this theme has more to do with internal (employee) care.

Skills development and training opportunities for individuals were also regarded by the participants as a normative expectation due to the fact that it would create the opportunity for them to further their skills, and to make progress in their work environment. This is stipulated in the Skills Development Act, 97 of 1998 (South Africa, 1998) and the Skills Development Levies Act, 9 of 1999 (South Africa, 1999).

\section{Research question 3:}

Which factors influence the entitlement beliefs of students?

Results: The individual or normative expectation level of prospective employees can be justified by one or more of the following factors that shape the entitlement belief of that individual. The following reasons where identified by the participants in the interview:

- Qualification level

$65 \%$ of the participants stressed that, due to their level of qualification, the organisation had to comply with certain requirements before they would consider working there.

- Contribution to the company

$30 \%$ of the participants stated that their expectation beliefs were due to the potential they had to make a meaningful contribution to the company.

- Self-efficacy

$15 \%$ of the participants stated that they were hard workers and academic achievers, and that was why they should receive certain advantages from their future employer, e.g. a high salary.

- Labour market tendencies

$5 \%$ of the participants stated that their expectations were quite low due to the current labour market tendencies related to their field of expertise.

- Job experience levels

$5 \%$ of the participants stated that they already had previous work experience, so they believed that they were entitled to higher expectations than other students without experience

- Cost of living (at workplace location)

$30 \%$ of the participants stated that the main reason why they had a certain expectation belief was due to a survival need. They had to survive when they commenced work, so their income should be higher than their expenditure. 
Interpretation of results: From the interviews it was evident that the participants already had a clear idea of what they would prefer in future employment, but when asked what they should receive in future employment their first response was that they had not thought about that all that much. This actually confirms that a person's entitlement perceptions is a subliminal belief and that something affects the expectation levels of prospective employees, even though they had no prior experience in employment. This is where the factors that influence entitlement beliefs of prospective employees fit in because these factors determine an individual's entitlement perception, which in turn determines the level of expectation which that individual will display.

The first factor identified was the participants' level of qualification. The majority of the participants stated that they felt they should receive a certain salary, benefits and special considerations due to the fact that they had a tertiary qualification level. All of the participants would at least have a degree when they commenced work, and some of them would even have a post-graduate degree. Most of the responses from the participants stated that they and their parents or legal guardians had invested a lot of money and time in their qualification, and that was why they would not accept anything below a certain expectation margin that they had in mind. The participants even believed that they should get a better job than a person that had no degree at all. According to Branson, Leibbrandt and Zuze (2009) there is a positive link between tertiary education and access to the labour market. This study concluded that tertiary graduates were up to three times more likely to be formally employed than a person with only a matric certificate.

The second factor was the individuals potential to contribute to the company. Each individual is different in terms of skills, personality, ability and experience. Therefore some of the participants stated that they had a relative higher work expectation due to the fact that they would provide something unique to the company with their wide array of skills, abilities and knowledge. The participants stated that, during their degree study, they gained knowledge of the subject matter, communication skills, learning skills, creativity and they could, and would, influence the company with these skills. Some of the responses actually mentioned the phrase "bringing something new and unique to the company" as this implied that they wanted to apply their academic mind to the working environment.

The third factor identified was the self-efficacy levels of the participants. According to Coetzee and Schreuder (2010) self-efficacy refers to an individual's belief in his/her own capacity to perform a specific task or reach a specific goal, and also the belief that they could overcome obstacles and accomplish difficult tasks. The achieving of challenging goals in personal and academic situations in an individual's life has an effect on that person's self-efficacy and self-esteem levels. According to Coetzee and Schreuder (2010) an employee who has the confidence to take on and put in the required effort to complete a challenging task successfully, and who is optimistic about succeeding in the present situation and also in future, can persevere in goal-directed activities and even redirect activities to ensure goal achievement. In other words, if self-esteem and self-efficacy levels in an individual are high, that person would have higher expectations regarding future productivity and outcomes. In the interviews 
some of participants mentioned that they had an average of above $75 \%$, or they were very productive while obtaining their degree, and thus felt they could have higher organisational expectations than a person who had just obtained his/her degree.

The fourth factor was the current labour market tendency. According to Barker (2007) the labour market is an imaginary market place where labour is bought and sold. The labour market walks hand in hand with the current economy of a country; if the economy is excellent, there will be a higher employment rate, but if the economy is in a recession, there will be a lower employment rate. Organisational downsizing is always a possibility when the economy is in an unfavourable state (for an organisation), and rumours of retrenchments are also frequent in these times (Barker, 2007; Venter, 2006). This creates a problem for prospective employees due to the fact that they are dependent on the economy and labour market tendencies of the country they wish to work in. Another problem is that tertiary education is not necessarily appropriate for the needs of the economy. According to Barker (2007) some qualifications in humanities (for instance languages, social sciences, arts, communication) still form a major part of all qualifications awarded, although the proportion has declined since 1992. There is still a sharp increase in the number of qualifications awarded in business, commerce and management. This leads to an oversupply of labour in certain qualification areas, for instance business management, which has the potential to shape an individual's (who has that qualification) expectation level.

The second factor was the participant's previous job experience level. Only one of the participants had relevant work experience, excluding temporary (student) employment. Even though no one else had relevant work experience, it did not prevent the participants from stating that job experience was worth much more in the workplace than a degree. According to Pop and Barkhuizen (2010) firms are generally not able to use new graduates to fill their skills requirements due to the fact that graduates have the qualifications but not the necessary practical skills and experience. In other words, a person who has job-related experience may feel more entitled to be considered for a position than a person without job experience.

The last factor is the general cost of living at the workplace location. Cost of living is one of the most important reasons the participants identified for their entitlement beliefs. Most of the interviewees were still dependant on their parents or legal guardians, and on the day that they commenced work, they would have to survive on their own. The emphasis in this theme is on the survival of the individual. They would need the basic necessities in order for them to survive, for instance accommodation, petrol and food. These few expenditures were just a few examples of the total expenditure. $30 \%$ of the participants stated they believed they should receive a minimum salary that would at least cover their basic expenditure and necessities and would enable them to survive.

The previous section of the paper explored and documented all the themes regarding expectations and entitlement beliefs of prospective employees by utilising a research proposition approach. In the following section a structural model will be presented on the anticipatory psychological contract of an individual. 


\section{Entitlement beliefs and anticipatory psychological contract model}

Utilising the results and interpretations of the data a structural model was developed that represents the entitlement beliefs and anticipatory psychological contract of a prospective employee.

This was achieved by grouping all the expectations together, and then grouping all the perceived entitlement factors together; then linking them in such a way that the individual's entitlement perceptions are influenced by certain factors. In turn this entitlement perception determines the expectation level of that individual. An entitlement beliefs and anticipatory psychological contract model can be seen in Figure 1.

In theory, if a person has a high level of perceived entitlement based on one or more factors that influence the entitlement beliefs, they would have higher job expectations, for instance better pay and more benefits than what the average individual has (individual expectation). On the other hand, if a person has an average entitlement belief, that person will have a normative level of expectation (normative expectations) for instance, a salary that covers the basic cost of living with certain necessity company benefits, for example a pension fund.

Figure 1: An entitlement beliefs and anticipatory psychological contract model

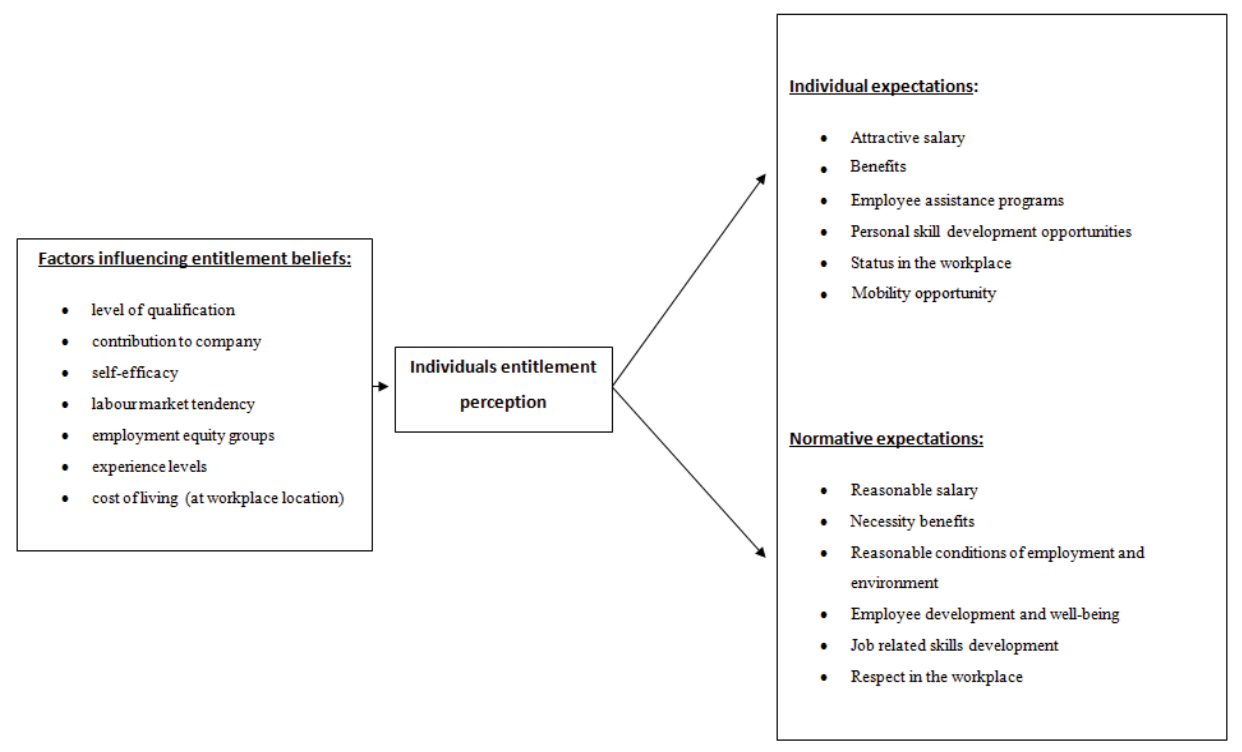

\section{Discussion and conclusion}

The main objective of this paper was to explore and substantiate themes associated with perceived entitlement and utilise this information to develop a structural model of the anticipatory psychological contract that would broaden the scope of perceived entitlement and psychological contract literature in the employment context.

To achieve this objective a literature study was conducted to better understand the psychological contract and perceived entitlement, and how these two constructs are interrelated. The next step was that themes regarding the expectations and entitle- 
ment beliefs of prospective employees were obtained and explored, ultimately to broaden the theory of perceived entitlement in the workplace. This was achieved by conducting interviews with participants and asking questions to identify the entitlement beliefs and expectations of prospective employees.

This paper identified two main constructs, namely expectations of prospective employees and factors that influence the expectations (entitlement beliefs) of prospective employees. The construct of expectations of prospective employees was further divided into two sub-constructs - individual expectations and normative expectations. These constructs and themes can aid in better understanding the underlying perceived entitlement beliefs of prospective employees and how they shape the individual's expectation level.

By using the various constructs and themes associated with a prospective employee's entitlement beliefs and expectations, a structured model was suggested to understand the anticipatory psychological contract of a prospective employee better.

From the findings it is evident that there is a difference between the expectations and perceived entitlements that prospective employees have. The main difference is that, if an individual has a certain expectation regarding the workplace and that expectation is not met by the employer, the individual will still settle for less. According to Hellgren (2003) this will constitute a breach of the psychological contract. But if that person has an entitlement belief regarding the workplace, that person will not settle for anything less than what they feel they are entitled to; in other words, this will have a negative impact on the relationship between the employee and the employer. Harvey and Martinko (2009) observed a positive relationship between perceived entitlement and turnover intent. This actually confirms that perceived entitlement is a component of the psychological contract due to the fact that, if a person had an entitlement belief in the workplace and the employer did not meet the entitlement demands, that person would definitely feel a greater breach or violation of the psychological contract and would ultimately resign or start looking for other work. According to Pop and Barkhuizen (2010) turnover is very high among newly working graduates in South-Africa. This failure of organisations to meet the entitlement beliefs of prospective employees may be one of the reasons why turnover is so high among new working graduates.

By fully comprehending the effect entitlement beliefs have on the anticipatory psychological contract of prospective employees, the employer may minimise the occurrence of psychological contract breach or violation, which may decrease turnover intention of new working graduates.

The themes derived from the study also have theoretical relevance to the literature for perceived entitlements in the workplace. From the qualitative research gathered in this study, the three basic entitlement beliefs of prospective employees are necessity of remuneration, reasonable conditions of employment and environment, and employee well-being and development. Although some of these findings are also identified in other studies on psychological contracts, it is striking to see that expectations such as fair treatment, trust, safety at work, job security and additional benefits (for example company car, child care provisions) are not listed in this study. 
The factors identified that influence the level of an individual's entitlement beliefs are the level of qualification of an individual, the individual's belief that he/she will contribute to the company, the individual's self-efficacy levels, current labour market tendencies, the individual's association with an employment equity group, the individual's work experience level, and the general cost of living (survival). From the interviews it became clear that the main sources for prospective employees to generate ideas regarding future employment were interaction with friends and family, information on employment opportunities, and societal norms.

Entitlement beliefs are determined by factors pertaining to the individual, and factors due to association with groups. It is important to note that homogenous groups may experience similar entitlement beliefs due to legislation, demographic area or societal norms. For instance, a group of people may have a higher entitlement belief regarding future employment in the city - due to cost of living being higher than in urban areas - than a group that wants to work in an urban area. This may also apply between members of certain race groups, gender groups and sectors in South Africa.

Another interesting finding of the study is that none of the participants actually stated that they were entitled to a better situation (or conditions) than what they were in currently. All of the participants are still students and none of them is in any sort of formal employment, thus a legitimate entitlement belief should have been that they should at least have a higher living standard than what they were currently experiencing. This actually reinforces that the main entitlement belief of prospective employees is monetary reward, as one of the participants stated:

"All that we as students are basically looking for is a good salary."

\section{Limitations}

This study had several limitations. Firstly, this research only included graduates who have not yet entered formal employment. When graduates start working it is possible that their expectations may change based on their experiences. Secondly, the study of entitlement beliefs and the anticipatory psychological contract was not researched through a quantitative research method. An exploratory qualitative study was performed to establish themes and propose a structural model. Thirdly, the results of this study cannot be generalized to the whole population due to the specific context of the study. It is important to note that this study focuses on the South-African graduate population. Certain unique entitlements can exist within this context, such as the entitlements associated with being part of a designated group. Although we took care to prevent issues of anonymity and confidentiality, this could have influenced the response of the participants. Finally, it was challenging to compare entirely different responses, causes by the idiosyncratic nature of the subjective perceptions of the participants.

\section{References}

Allers, K. L. (2005). Where there's a will, there's a fray. Fortune, 152(8). Retrieved from http://money.cnn.com/magazines/fortune/

Barker, F. (2007). South African labour market: Theory and practice (5th ed.). Pretoria, South Africa: Van Schaik publishers. 
Boyd, H. C., \& Helms, J. E. (2005). Consumer entitlement theory and research. Psychology and Marketing, 22, 271-286.

Branson, N., Leibbrandt, M., \& Zuze, T. L. (2009). The demand for tertiary education in South Africa. South African Labour and Development Research Unit, 1-68.

Campbell, W. K., Bonacci, A. M., Shelton, J., Exline, J. J., \& Bushman, B. J. (2004). Psychological entitlement: Interpersonal consequences and validation of a self-report measure. Journal of Personality Assessment, 83(1), 29-45.

Coetzee, M., \& Schreuder, D. (2010). Personnel psychology: An applied perspective. Cape Town: Oxford University Press, Southern Africa.

De Vos, A., De Stobbeleir, K., \& Meganck, A. (2009). The relationship between career-related antecedents and graduates' anticipatory psychological contract. Journal of Business Psychology, 24, 289-298.

Exline, J. J., Baumeister, R. F., Bushman, B. J., Campbell, W. K., \& Finkel, E. J. (2004). Too proud to let go: Narcissistic entitlement as a barrier to forgiveness. Journal of Personality and Social Psychology, 87(6), 894-912.

Fisk, G. M. (2010). "I want it all and I want it now!" An examination of the etiology, expression, and escalation of excessive employee entitlement. Human Resource Management Review, 20, 102-114.

Freese, C., \& Schalk, R. (2008). How to measure the psychological contract? A critical criteria-based review of measures. South African Journal of Psychology, 38(2), 269-286.

Greenberger, E., Lessard, J., Chen, C., \& Farruggia, S. P. (2008). Self-entitled college students: Contributions of personality, parenting, and motivational factors. Journal of Youth and Adolescence, 37, 11931204.

Grobler, P. A., Wärnich, S., Carrell, M. R., Elbert, N. F., \& Hatfield, R. D. (2006). Human resource management in South Africa (3rd ed.). London, United Kingdom: South-Western, Cengage Learning.

Harvey, P., \& Harris, K. J. (2010). Frustration-Based outcomes of entitlement and the influence of supervisor communication. Human Relations, 63(11), 1639-1660.

Harvey, P., \& Martinko, M. J. (2009). An empirical examination of the role of attributions in psychological entitlement and its outcomes. Journal of Organizational Behavior, 30(4), 459-476.

Heath, C., Knez, M., \& Camerer, C. (1993). The strategic management of the entitlement process in the employment relationship. Strategic Management Journal, 14, 75-93.

Hellgren, J. (2003). The times they are a-changin': Job uncertainty and the flexible labor market. Edsbruk, Sweden: Akademitryck.

Kets de Vries, M. F. R. (2006). The spirit of despotism: Understanding the tyrant within. Human Relations, 59(2), 195-220.

Kreitner, R., \& Kinicki, A. (2008). Organizational behavior (8th ed.). New York, NY: McGraw-Hill.

Levine, D. P. (2005). The corrupt organization. Human Relations, 58(6), 723-740.

Levinson, H., Price, C., Munden, K., Mandl, H., \& Solley, C. (1962). Men, management and mental health. Cambridge, MA: Harvard Press.

Linde, B, J. (2007). Employment relations, the psychological contract and work wellness in the higher education sector in South Africa. Ridderkerk, the Netherlands: Ridderprint B.V.

Mohr, P., \& Fourie, L. (2006). Ekonomie vir Suid-Afrikaanse studente [Economics for South-African students] (3rd ed.). Pretoria, South Africa: Van Schaik publishers.

Morrison, E., \& Robinson, S. (1997). When employees feel betrayed: A model of how psychological contract violations develop. Academy of Management Review, 22, 226-256.

Naumann, S. E., Minsky, B. D., \& Sturman, M. C. (2002). The use of the concept "entitlement" in management literature: A historical review, synthesis, and discussion of compensation policy implications. Human Resource Management Review, 12, 145-166.

Newell, S. (2002). Creating the healthy organization: Well-being, diversity \& ethics at work. London: Thomson Learning.

Ochse, C. (2005). Race differences in academic expectations and perceptions of ability in relation to actual achievement. South African Journal of Higher Education, 19(2), 334-344.

Oxford Dictionary. (2010). Oxford advanced learner's dictionary: International student's edition. (7th ed.). Cape Town, South Africa: Oxford University Press. 
Paul, R. J., Niehoff, B. P., \& Turnley, W. H. (2000). Empowerment, expectations, and the psychological contract - managing the dilemmas and gaining the advantages. Journal of Socio-Economics, 29, 471-485.

Pop, C., \& Barkhuizen, N. (2010). The relationship between skills training and retention of graduate interns in a South African information, communication and technology company. Literacy Information and Computer Education Journal, 1(2), 1-9.

Restubog, S. L. D., Bordia, P., \& Tang, R. L. (2006). Effects of psychological contract breach on performance of IT employees: The mediating role of affective commitment. Journal of Occupational and Organizational Psychology, 79, 299-306.

Robinson, S. L., \& Rousseau, D. M. (1994). Violating the psychological contract: not the exception but the norm. Journal of Organizational Behavior, 15, 245-259.

Rousseau, D. M. (1989). Psychological and implied contracts in organizations. Employee Responsibilities and Rights Journal, 2, 121-139.

Rousseau, D. M. (1995). Psychological contracts in organizations: Understanding written and unwritten agreements. Thousand Oaks, CA: Sage.

Rousseau, D. M. (1998). The "problem" of the psychological contract considered. Journal of Organizational Behavior, 19, 665-671.

Rousseau, D. M. (2001). Schema, promise and mutuality: The building blocks of the psychological contract. Journal of Occupational and Organizational Psychology, 74, 511-541.

SAGRA. (2011). The SAGRA graduate recruitment survey 2011. Retrieved from http://www.sagra.org.za/

Schwartz, J., Tylka, T. (2008). Exploring entitlement as a moderator and mediator of the relationship between masculine gender role conflict and men's body esteem. Psychology of Men and Masculinity, 9(2), 67-81.

Scott, L.W., Eau, C., \& Jill, K. (2001). Psychological contracts in the $21^{\text {st }}$ century: What employees value most and how well organizations are responding to these expectations. Human Resource Planning, 24, $10-21$.

Snyders, F. J. A. (2002). The dangers of entitlement. Unisa Psychologia, 28, 21-23.

South Africa. (1998). Skills Development Act, no 97 of 1998. Government Printer: Pretoria.

South Africa. (1999). Skills Development Levies Act, no 9 of 1999. Government Printer: Pretoria.

Statistics South Africa. (2010). Monthly Earnings of South Africans 2010. Retrieved from http://www.statssa.gov.za/

Sutton, G., \& Griffin, M. A. (2004). Integrating expectations, experiences and psychological contract violations: A longitudinal study of new professionals. Journal of Occupational and Organizational Psychology, 77, 493-514.

Trochim, W. M. K., \& Donnelly, J. P. (2008). The research methods knowledge base (3rd ed.). Mason, OH: Cengage Learning, Atomic Dog.

Turnley, W. H., Bolino, M. C., Lester, S. W., \& Bloodgood, J. M. (2003). The impact of psychological contract fulfilment on the performance of in-role and organizational citizenship behaviours. Journal of Management, 29(2), 187-206.

Turnley, W. H., \& Feldman, D. C. (1999). A discrepancy model of psychological contract violations. Human Resource Management Review, 9, 367-386.

Twenga, M., \& Campbell, W. K. (2009). The narcissism epidemic: Living in the age of entitlement. New York, NY: Free Press, Simon \& Schuster Inc.

Tyre, P., Scelfo, J., \& Kantrowitz, B. (2004). The power of no. Newsweek, 144(11), 42-51.

VandenBos, R. (2006). APA dictionary of psychology. Washington, DC: American Psychological Association.

Van den Heuvel, S., \& Schalk, R. (2009). The relationship between fulfilment of the psychological contract and resistance to change during organizational transformations. Social Science Information, 48(2), 283-313.

Venter, R. (2006). Labour relations in South Africa (Rev. ed.). Cape Town, South Africa: Oxford University Press. 